\title{
Bacteriological Analysis of Ready- to- serve Foods from a South Indian City: A Potential Source for Drug Resistant Pathogens
}

\author{
Aruna Siddabathuni \\ Department of Microbiology, GSL Medical College and General Hospital, Rajahmundry, Andhra Pradesh, India
}

\begin{abstract}
Objective: Street foods are well - known source for bacteriological contamination with pathogens, responsible for health hazards like food poisoning and diarrheal diseases. The present study was undertaken to analyze the bacteriological quality of ready - to - serve foods vended in the streets of Rajahmundry, Andhra Pradesh, India.

Method: This cross-sectional study over a 6-month period tested 142 diverse locally sold street foods collected from different locations in Rajahmundry city. Isolates obtained were identified to the species level and antibiotic susceptibility patterns determined. Additional information regarding food preparation, storage and handling practices observed by vendors was noted to correlate with the extent of bacterial contamination.
\end{abstract}

Results: Majority $(71.12 \%)$ of the ready to eat foods were contaminated with bacteria. Samosa $(24 \%)$ and panipuri $(22 \%)$ showed higher bacterial contamination rates. Of the total 177 strains recovered from all street foods, Escherichia coli (44\%) and Staphylococcus aureus (29\%) were the major isolates. Staphylococcus aureus (23\%) was predominantly isolated from panipuri samples; Proteus species (29\%) from masala chat; $E$. coli (31\%) from Samosa; Klebsiella pneumoniae $(40 \%)$ from Samosa; Pseudomonas aeruginosa $(40 \%)$ from panipuri. Higher degrees of bacterial contamination were associated with poor personnel hygiene of vendors and unsafe food handling practices. Among the isolates, $33 \%$ of $E$. coli were extended spectrum beta lactamase (ESBL) producers while $15 \%$ were Methicillin resistant Staphylococcus aureus.

Conclusions: Corrective measures like provision of health education to vendors and strict regulations for implementation of good hygienic practices would improve street foods quality. J Microbiol Infect Dis 2019; 9(2):8389.

Keywords: Bacterial contamination, Street foods, Escherichia coli, Staphylococcus aureus, Pseudomonas aeruginosa

\section{INTRODUCTION}

The street food industry is flourishing on a daily basis as economical and readily available food items are fulfilling the food requirements of city inhabitants in many developing countries. Consumption of street foods has been a rapidly growing trade in many Indian cities due to limited work opportunities, high unemployment, low salaries and ongoing rapid urbanization [1]. Safety becomes the major concern as these foods are well known for bacterial contamination leading to food poisoning. Food borne infections associated with street foods is a matter of public health concern.

Common causes implicated in bacterial contamination of ready - to - eat foods, include poor personal hygiene maintained by food vendors; preparation under unclean surroundings, uncovered roadside display of foods and improper food storage conditions. Quality and safety standards are of little concern to customers who depend on them for the sake of convenience [1-3]. Most of the street food vendors are illiterate, not trained and lack knowledge regarding the transmission of food borne infections [4]. Pathogens may reach these foods either during preparation, after cooking or while handling $[5,6]$.

Several cases of food borne infections due to ready - to - serve foods were reported from India [6-8] and abroad [9-11]. A study conducted at Amaravati city located in south Indian state of

Correspondence: Dr. Aruna Siddabathuni, Department of Microbiology, GSL Medical College and General Hospital, Rajahmundry, Andhra Pradesh, India

E-mail: achantaaruna22@gmail.com

Received: 09 July 2018 Accepted: 07 June 2019

Copyright (C JMID / Journal of Microbiology and Infectious Diseases 2019, All rights reserved 
Maharashtra [12] revealed a high degree of bacterial contamination in street foods (92 bacterial isolates obtained from 55 food samples analyzed). The bacterial pathogens identified were Pseudomonas aeruginosa (39\%), Escherichia coli (21\%), Staphylococcus aureus (16\%), Salmonella sp. (12\%) and Proteus sp. $(12 \%)$. other study from Pune city found $88 \%$ of street foods to be contaminated with several bacteria like $P$. aeruginosa, E. coli, $S$. aureus, Enterobacter and Klebsiella [8]. Out of 60 street food samples tested from another south Indian city, Mangalore, 56 (93\%) were contaminated with bacteria. Significant Coliform count was detected in 21 samples. All the items which had high bacterial count were prepared and served in places where the washing of hands, utensils and dishes was done in buckets [7].

Owing to progressive increase in occurrence of drug resistant food borne pathogens particularly in developing countries, laboratories need to periodically monitor the changing trends in antibiogram of food borne pathogens [10,11]. Unrestricted over the counter sale of antibiotics and lack of awareness in general public regarding the adverse effects of antibiotic misuse contributed to this scenario. Both the government and health care professionals need to educate the public and make them aware of potential health hazards related to consumption of ready - to - eat foods sold on streets.

Rajahmundry is a populous city located on the banks of river Godavari in East Godavari district in the South Indian State of Andhra Pradesh. It is known as cultural capital of Andhra Pradesh with well-established street food industry to meet the food demands of residents and visitors from all over India. The present study was undertaken to assess the bacteriological quality of popularly sold and consumed street foods in this city as no previous data was available on this regard. The antibiogram of locally prevalent food borne pathogens was examined. The routine handling practices used by vendors that may contribute to food-borne infections were also recorded and analyzed.

\section{METHODS}

\section{Study design, sample size and collection}

The present cross-sectional study conducted over a six-month period (July 2017 to December 2017) included 142 diverse food items sampled from several well-known street food vending localities in the city of Rajahmundry. Institutional ethical committee approval was obtained and food items were randomly collected from different locations that included local Indian fried savouries like bhelpuri, panipuri, samosa, chat, mirchi bajji, noodles prepared from gram/allpurpose flour with mixed vegetables; a fried sweet dish jalebi, and fried rice consumed on roadsides. These samples were collected aseptically in sterile containers, and then placed in a box loaded with ice packs and transferred to Microbiology laboratory for further processing.

\section{Sample processing}

One gram of each sample was diluted with $10 \mathrm{ml}$ of sterile distilled water. A $0.5 \mathrm{ml}$ volume of this diluted food sample was transferred to $4.5 \mathrm{ml}$ of MacConkey broth and incubated for 5-6 hrs. Microbial growth was observed as turbidity developed in the broth. This broth is then sub cultured on to Cysteine Lactose Electrolyte Deficient agar (CLED) and incubated at $37{ }^{\circ} \mathrm{C}$ for $24 \mathrm{hrs}$. period.

Preliminary identification of isolates was done by study of gram staining, motility, catalase and oxidase tests, color and growth characteristics on CLED - yellow colonies of $E$. coli, blue colonies of $P$. aeruginosa, mucoid yellow colonies of Klebsiella pneumoniae and green colored colonies of Proteus species [12,13].

Identification of bacterial isolates was confirmed by subculturing on appropriate selective media like Mannitol salt agar for $S$. aureus, MacConkey agar for Enterobacteriaceae, Xylose lysine Deoxycholate agar for Salmonella and Shigella species and other biochemical tests like catalase, coagulase, oxidase, indole, citrate utilization, urease production, sugar fermentation and reaction on triple sugar iron agar [14].

Along with food samples, structured information regarding location of the vending site, no. of vendors handling food, hygienic and sanitary practices of vendors, cleanliness of utensils, time interval between food preparation and sale, method of cooking food, quality of water used in food preparation was noted and recorded in data collection sheet to correlate degrees of bacterial contamination in different foods with various risk factors. Statistical analysis of data was done with SPSS Software version 20.0. Chi square 
test was performed to assess the association among various categorical variables and a $p$ value $<0.05$ was considered as statistically significant.

\section{Antimicrobial susceptibility testing}

All the isolates were subjected to susceptibility testing by Kirby-Bauer disc diffusion method with ampicillin $(10 \mu \mathrm{g})$, piperacillin tazobactum (15 $\mu \mathrm{g})$, ciprofloxacin $(15 \mu \mathrm{g})$, gentamicin $(10 \mu \mathrm{g})$, imipenem $(30 \mu \mathrm{g})$, Cefepime $(30 \mu \mathrm{g})$, cefotaxime $(30 \mu \mathrm{g})$ and ceftazidime $(30 \mu \mathrm{g})$.

Most frequently isolated gram negative bacterial pathogens were further confirmed for extended spectrum beta lactamase (ESBL) production by combined disc test (CDT) while all $S$. aureus isolates were tested for methicillin resistance by Cefoxitin disc diffusion test[15,16] .

\section{RESULTS}

The study analyzed 142 food samples of different variety: Samosa, panipuri, bhelpuri, noodles, fried rice, masala chat, mirchi bajji and jalebi for the extent of bacterial contamination. Out of total 142 food samples tested, 101 $(71.1 \%)$ were contaminated with one or more bacterial strains grown on culture. Among different food variants samosa (84.2\%), panipuri $(80.6 \%)$ and noodles $(78.5 \%)$ showed higher frequencies of bacterial contamination. Table 1 denotes item wise and overall comparison of contaminated and non-contaminated food samples.

A total of 177 bacterial isolates were recovered on culturing 101 contaminated samples. Samosa yielded highest number of bacterial pathogens (24\%) followed by panipuri (22\%) and noodles (12\%) (Table 2). Among various bacterial species obtained $S$. aureus (23\%) was predominantly isolated from panipuri samples; Proteus sp. (29\%) from masala chat; E.coli (31\%) from Samosa; K. pneumoniae (40\%) from Samosa; $P$. aeruginosa (40\%) from panipuri. Salmonella and Shigella were not isolated from contaminated foods (Table 3 ).

Table 4 depicts the association between degree of bacterial contamination and unhygienic cooking, handling and serving practices of vendors. Higher number of bacterial pathogens were recovered from foods collected from crowded areas (80\%) compared to non crowded sites (20\%). Foods sold either by

owner or a single worker were found to be less contaminated (42\%) than those served by two or more servants $(58 \%)$. Significant occurrence of bacterial pathogens was noted from locations showing poor personnel hygiene of vendors $(52 \%)$, poor sanitary conditions of surroundings (48\%), improper food storage conditions $(70 \%)$ and inadequate cleaning of utensils (53\%) (Table 4).

Table 1.Degree of contamination in various street foods.

\begin{tabular}{lcc}
\hline Food item (n) & Cont. (\%) & Non-cont. (\%) \\
\hline Samosa (38) & $32(84.2)$ & $6(15.8)$ \\
\hline Panipuri (31) & $25(80.65)$ & $6(19.35)$ \\
\hline Bhelpuri (12) & $6(50)$ & $6(50)$ \\
\hline Noodles (14) & $11(78.57)$ & $3(21.43)$ \\
\hline Fried rice (11) & $6(54.55)$ & $5(45.45)$ \\
\hline Masala chat (15) & $10(66.67)$ & $5(33.33)$ \\
\hline Mirchi bajji (8) & $3(37.5)$ & $5(62.5)$ \\
\hline Jalebi (13) & $8(61.54)$ & $5(38.46)$ \\
\hline Total (142) & $101(71.13)$ & $41(28.87)$ \\
\hline Cont.=Contaminated, Non-cont.=Non-contaminated
\end{tabular}

Antimicrobial susceptibility patterns of bacterial pathogens were documented in Table 5. E. coli strains showed good susceptibility to imipenem (100\%), gentamicin (97\%), ciprofloxacin (76\%) while poor susceptibility was noted to ceftazidime (54\%), cefotaxime (44\%), Cefepime (42\%) and ampicillin (37\%).

Table 2. Load of bacterial pathogens from various street foods.

\begin{tabular}{lcc}
\hline Food type & $\begin{array}{c}\text { No. of Cont. } \\
\text { samples }\end{array}$ & $\begin{array}{c}\text { No. of bacterial } \\
\text { pathogens isolated (\%) }\end{array}$ \\
\hline Samosa & 32 & $42(24 \%)$ \\
\hline Panipuri & 25 & $39(22 \%)$ \\
Bhelpuri & 6 & $14(8 \%)$ \\
Noodles & 11 & $21(12 \%)$ \\
\hline Fried rice & 6 & $15(8.4 \%)$ \\
Masala chat & 10 & $18(10 \%)$ \\
Mirchi bajji & 3 & $11(6 \%)$ \\
Jalebi & 8 & $17(9.6 \%)$ \\
\hline Total & 101 & $177(100 \%)$ \\
\hline Cont.=Contaminated & \\
\end{tabular}


Table 3. Bacterial species recovered from different food varieties.

\begin{tabular}{lcccccc}
\hline Food variety & \multicolumn{7}{c}{ No. of Bacterial isolates recovered } \\
\cline { 2 - 7 } & $\begin{array}{c}\text { S. aureus, } \mathbf{n} \\
\mathbf{( \% )}\end{array}$ & $\begin{array}{c}\text { Proteus species, } \\
\mathbf{n}(\%)\end{array}$ & $\begin{array}{c}\boldsymbol{E} \text {. coli, } \mathbf{n} \\
\mathbf{( \% )}\end{array}$ & $\begin{array}{c}\text { K. pneumoniae, } \mathbf{n} \\
\mathbf{( \% )}\end{array}$ & $\begin{array}{c}\boldsymbol{P} \text {. } \\
\text { aeruginosa }\end{array}$ & Total \\
\hline Samosa & $9(17)$ & $4(17 \%)$ & $24(31 \%)$ & $4(50 \%)$ & $2(13 \%)$ & 42 \\
Panipuri & $12(23)$ & $6(25 \%)$ & $11(14 \%)$ & $3(38 \%)$ & $6(40 \%)$ & 39 \\
Bhelpuri & $5(10)$ & $4(17 \%)$ & $6(8 \%)$ & 0 & 0 & 14 \\
Noodles & $9(17)$ & $2(8 \%)$ & $8(10 \%)$ & 0 & $1(7 \%)$ & 21 \\
Fried rice & $8(15)$ & 0 & $7(9 \%)$ & 0 & 0 & 15 \\
Masala chat & $0(0)$ & $7(29 \%)$ & $10(13 \%)$ & $1(12 \%)$ & $1(7 \%)$ & 18 \\
Mirchi bajji & $4(8)$ & 0 & $7(9 \%)$ & 0 & 0 & 11 \\
Jalebi & $5(10)$ & $1(4 \%)$ & $5(6 \%)$ & 0 & $5(33 \%)$ & 17 \\
Total & $52(29)$ & $24(14 \%)$ & $78(44 \%)$ & $8(5 \%)$ & $15(8 \%)$ & $177(100 \%)$ \\
\hline
\end{tabular}

Table 4. Association between bacterial contamination and sanitation cum hygienic practices observed by vendors.

\begin{tabular}{|c|c|c|c|c|c|c|c|c|}
\hline \multirow[b]{2}{*}{ Parameter } & \multirow[b]{2}{*}{ Condition } & \multicolumn{6}{|c|}{ Bacterial pathogens } & \multirow[b]{2}{*}{$\begin{array}{l}\text { Chi } \\
\text { square } \\
\text { value }\end{array}$} \\
\hline & & $\begin{array}{c}S . \\
\text { aureus } \\
\mathrm{n}=52\end{array}$ & $\begin{array}{c}\text { Proteus } \\
\text { species } \\
\mathrm{n}=24\end{array}$ & $\begin{array}{c}E . c o l i \\
n=78\end{array}$ & $\begin{array}{c}\text { K. } \\
\text { pneumoniae } \\
\mathrm{n}=8\end{array}$ & $\begin{array}{c}P . \\
\text { aeruginosa } \\
n=15\end{array}$ & $\begin{array}{l}\text { Total } \\
\mathrm{n}=177\end{array}$ & \\
\hline \multirow{2}{*}{ Vending site } & $\begin{array}{l}\text { Heavily } \\
\text { crowded }\end{array}$ & $43(83 \%)$ & $18(75 \%)$ & $\begin{array}{c}65 \\
(83 \%)\end{array}$ & $6(75 \%)$ & $9(60 \%)$ & $\begin{array}{c}141 \\
(80 \%)\end{array}$ & \multirow{2}{*}{$124.5^{\star \star}$} \\
\hline & $\begin{array}{l}\text { Less } \\
\text { crowded }\end{array}$ & $9(17 \%)$ & $6(25 \%)$ & $\begin{array}{c}13 \\
(17 \%)\end{array}$ & $2(25 \%)$ & $6(40 \%)$ & $\begin{array}{c}36 \\
(20 \%)\end{array}$ & \\
\hline \multirow{3}{*}{$\begin{array}{l}\text { Personal hygiene of } \\
\text { vendors }\end{array}$} & Good & $12(23 \%)$ & $6(25 \%)$ & $\begin{array}{c}12 \\
(15 \%)\end{array}$ & $1(12 \%)$ & $5(33 \%)$ & $\begin{array}{c}36 \\
(20 \%)\end{array}$ & \multirow{3}{*}{$43.6^{* *}$} \\
\hline & Fair & $17(33 \%)$ & $5(21 \%)$ & $\begin{array}{c}21 \\
(27 \%)\end{array}$ & $3(38 \%)$ & $3(20 \%)$ & $\begin{array}{c}49 \\
(28 \%)\end{array}$ & \\
\hline & Poor & $23(44 \%)$ & $13(54 \%)$ & $\begin{array}{c}45 \\
(58 \%)\end{array}$ & $4(50 \%)$ & $7(47 \%)$ & $\begin{array}{c}92 \\
(52 \%)\end{array}$ & \\
\hline \multirow{3}{*}{$\begin{array}{l}\text { Cleanliness of } \\
\text { utensils }\end{array}$} & Good & $8(15 \%)$ & $7(29 \%)$ & $\begin{array}{c}14 \\
(18 \%)\end{array}$ & $4(50 \%)$ & $3(20 \%)$ & $\begin{array}{c}36 \\
(20 \%)\end{array}$ & \multirow{3}{*}{$48.2^{* *}$} \\
\hline & Fair & $16(31 \%)$ & $9(38 \%)$ & $\begin{array}{c}16 \\
(21 \%)\end{array}$ & $2(25 \%)$ & $4(27 \%)$ & $\begin{array}{c}47 \\
(27 \%)\end{array}$ & \\
\hline & Poor & $28(54 \%)$ & $8(33 \%)$ & $\begin{array}{c}48 \\
(61 \%)\end{array}$ & $2(25 \%)$ & $8(53 \%)$ & $\begin{array}{c}94 \\
(53 \%)\end{array}$ & \\
\hline \multirow{2}{*}{ No. of vendors } & One & $18(35 \%)$ & $11(46 \%)$ & $\begin{array}{c}36 \\
(46 \%)\end{array}$ & $3(38 \%)$ & $7(47 \%)$ & $\begin{array}{c}75 \\
(42 \%)\end{array}$ & \multirow{2}{*}{$8.2^{*}$} \\
\hline & $\begin{array}{c}\text { Two or } \\
\text { more }\end{array}$ & $34(65 \%)$ & $13(54 \%)$ & $\begin{array}{c}42 \\
(54 \%) \\
\end{array}$ & $5(62 \%)$ & $8(53 \%)$ & $\begin{array}{c}102 \\
(58 \%)\end{array}$ & \\
\hline \multirow{2}{*}{$\begin{array}{l}\text { Food storage } \\
\text { conditions }\end{array}$} & Good & $8(15 \%)$ & $9(38 \%)$ & $\begin{array}{c}25 \\
(32 \%)\end{array}$ & $5(62 \%)$ & $6(40 \%)$ & $\begin{array}{c}53 \\
(30 \%)\end{array}$ & \multirow{2}{*}{$56.9^{* *}$} \\
\hline & Poor & $44(85 \%)$ & 15 (62\%) & $\begin{array}{c}53 \\
(68 \%)\end{array}$ & 3 (38\%) & $9(60 \%)$ & $\begin{array}{l}124 \\
(70 \%)\end{array}$ & \\
\hline \multirow{3}{*}{$\begin{array}{l}\text { Sanitation at vending } \\
\text { site }\end{array}$} & Good & $11(21 \%)$ & $8(33 \%)$ & $\begin{array}{c}17 \\
(22 \%)\end{array}$ & 3 (37.5\%) & $1(7 \%)$ & $\begin{array}{c}40 \\
(23 \%)\end{array}$ & \multirow{3}{*}{$27.6^{* *}$} \\
\hline & Fair & 17 (33\%) & 7 (29\%) & $\begin{array}{c}22 \\
(28 \%)\end{array}$ & 2 (25\%) & $4(27 \%)$ & $\begin{array}{c}52 \\
(29 \%)\end{array}$ & \\
\hline & Poor & 24 (46\%) & 9 (38\%) & $\begin{array}{c}39 \\
(50 \%)\end{array}$ & 3 (37.5\%) & $10(66 \%)$ & $\begin{array}{c}85 \\
(48 \%)\end{array}$ & \\
\hline \multirow{2}{*}{$\begin{array}{l}\text { Time delay between } \\
\text { food preparation and } \\
\text { sale }\end{array}$} & Long & 38 (73\%) & $13(54 \%)$ & $\begin{array}{c}62 \\
(79 \%)\end{array}$ & 5 (62\%) & $10(67 \%)$ & $\begin{array}{l}128 \\
(72 \%)\end{array}$ & \multirow{2}{*}{$70.5^{* *}$} \\
\hline & Short & $14(27 \%)$ & $11(46 \%)$ & $\begin{array}{c}16 \\
(21 \%)\end{array}$ & 3 (38\%) & $5(33 \%)$ & $\begin{array}{c}49 \\
(28 \%)\end{array}$ & \\
\hline
\end{tabular}

${ }^{*} p$ statistically significant at $<0.05 ;{ }^{* *} p$ statistically highly significant at $<0.001$ 
Table 5. Antimicrobial susceptibility profile of food borne bacterial pathogens.

\begin{tabular}{lccccc}
\hline \multirow{2}{*}{ Antibiotics } & \multicolumn{5}{c}{ No. of susceptible isolates } \\
\cline { 2 - 6 } & $\begin{array}{c}\text { E. coli } \\
(\mathbf{7 8 )}\end{array}$ & $\begin{array}{c}\text { S. aureus } \\
(\mathbf{5 2 )}\end{array}$ & $\begin{array}{c}\text { Proteus species } \\
\mathbf{( 2 4 )}\end{array}$ & $\begin{array}{c}\boldsymbol{P} \text {. aeruginosa } \\
(\mathbf{1 5 )}\end{array}$ & $\begin{array}{c}\text { K. pneumoniae } \\
\text { (8) }\end{array}$ \\
\hline Ampicillin & $29(37 \%)$ & $42(81 \%)$ & $19(79 \%)$ & $8(53 \%)$ & $6(75 \%)$ \\
Cefepime & $33(42 \%)$ & $38(73 \%)$ & $12(50 \%)$ & $5(33 \%)$ & $4(50 \%)$ \\
Cefotaxime & $34(44 \%)$ & $31(60 \%)$ & $13(54 \%)$ & $4(27 \%)$ & $5(63 \%)$ \\
Ceftazidime & $42(54 \%)$ & $45(87 \%)$ & $18(75 \%)$ & $9(60 \%)$ & $6(75 \%)$ \\
Piperacillin/tazobactum & $72(92 \%)$ & $51(98 \%)$ & $22(92 \%)$ & $14(93 \%)$ & $8(100 \%)$ \\
Ciprofloxacin & $59(76 \%)$ & $49(94 \%)$ & $23(96 \%)$ & $9(60 \%)$ & $7(88 \%)$ \\
Gentamicin & $67(86 \%)$ & $39(75 \%)$ & $22(92 \%)$ & $11(73 \%)$ & $6(75 \%)$ \\
Imipenem & $78(100 \%)$ & $0(0 \%)$ & $24(100 \%)$ & $15(100 \%)$ & $8(100 \%)$ \\
\hline
\end{tabular}

Strains resistant to cefotaxime and ceftazidime were further confirmed for ESBL production by combined disc test as per CLSI guidelines.

Among $78 \mathrm{E}$. coli isolates tested for ESBL production $26(33 \%)$ were found positive. Out of 26 ESBL producers, 13 were resistant to ciprofloxacin and 11 were resistant to gentamicin and 6 to piperacillin/tazobactum. Majority of $S$. aureus isolates showed good susceptibility to almost all tested antibiotics (Table 5). Of the $52 S$. aureus isolates, 8 were found to be MRSA strains.

Proteus species showed higher sensitivity levels to most of the tested antibiotics except Cefepime $(50 \%)$ and cefotaxime (54\%). P. aeruginosa strains showed highest sensitivity to imipenem $(100 \%)$, followed by piperacillin tazobactum (93\%), gentamicin $(73 \%)$, ceftazidime $(60 \%)$. Majority of Klebsiella pneumoniae isolates showed good sensitivity rates to most of tested antibiotics except Cefepime (50\%). Imipenem found to be active against all bacterial isolates.

\section{DISCUSSION}

Street foods are liable for bacterial contamination mainly due to defective manufacturing, handling and waste disposal practices of vendors. Most of the vendors are unaware of hazards of food borne pathogens and their modes of transmission. Present study attempted to analyze bacterial contamination rates among commonly sold ready - to - serve foods and to correlate potential risk factors with the extent of bacterial contamination.

This study revealed an overall high bacterial contamination rate $(71.1 \%)$ from various street food samples evaluated. Samosa and panipuri samples were heavily contaminated. Similar observation was made from studies by
Tambekar et al., 2008 from India [12]. A study by Bhaskar et al 2004 at Mangalore also demonstrated $93 \%$ bacterial contamination out of 60 street food samples tested [7]. In a Mexican study a total of 103 taco dressings were sampled for $E$. coli and Salmonella $s p$. They found $44(43 \%)$ contained E. coli and 5 (5\%) Salmonella [17]. Feglo et al, 2012 reported $100 \%$ contamination of various food samples collected from Kumasi, Ghana [18].

Among these foods, Samosa showed highest bacterial contamination (24\%) followed by panipuri $(22 \%)$. These foods were on high demand and hence prepared much earlier to consumption and kept uncovered exposed to dust and air pollution on roadsides. Least contamination was shown by mirchi bajji (6\%) probably due to their preparation shortly before consumption and repeated reheating as customers prefer to buy them hot.

A total of 177 bacterial pathogens were obtained from 101 culture positive samples. Overall E.coli (44\%) was the predominant isolate followed by S. aureus $(29 \%)$, Proteus species (14\%), P. aeruginosa $(8 \%)$ and $K$. pneumoniae $(5 \%)$. High load of E.coli (44\%) and Proteus species (14\%) among these foods could be associated with poor hand hygiene of vendors; use of contaminated water in food preparation with bare hands; contamination of utensils by pathogens carried by flies from nearby sewage and garbage [8,12]. Occurrence of $P$. aeruginosa in these foods might be attributed to inadequate personal hygiene of vendors and improper cleaning of utensils leading to food layer deposition that favors the growth of biofilms [12]. Causes for higher contamination rates with $S$. aureus $(29 \%)$ could be occurring from soiled clothes of workers, scratching the axilla or scalp, touching the hair, infected cuts or 
burn wounds (Table 3). Contamination with $K$. pneumoniae might be due to poor personal hygiene, deposition of aerosols generated by coughing or sneezing by customers or vendors.

A significant association between bacterial contamination of street foods and the improper sanitary and hygienic practices followed by vendors was depicted in Table 4. These findings correlated with studies by Tambekar et al., 2008 and Chumber et al., 2007 from India [8,12].

Among E.coli isolates $33 \%$ were found to be ESBL producers. Of the 26 ESBL producers, 13 were found resistant to ciprofloxacin; 11 to gentamicin and 6 to piperacillin /tazobactum. This could be due to ESBL plasmids harboring genes that also code for resistance to other classes like fluoroquinolones and aminoglycosides. Increased resistance rates to cephalosporins may be attributed to unrestricted over the counter sale and excessive and inappropriate use of their class of antibiotics in the community.

Self-medication of antibiotics without prescription might have created an inapparent reservoir of resistant organisms in the general population that is likely to contaminate street sold foods. Asymptomatic carriers may harbor drug resistant pathogens and spread them in the community leading to occurrence of multidrug resistant bacteria in community acquired infections. This is a major public health concern as infections by MDR pathogens were associated with increased mortality and morbidity rates. Among S.aureus isolates, 8 were found to be MRSA strains. Nasal carriage of these strains by healthy individuals can lead to their dissemination in the community. All MRSA strains were found sensitive to vancomycin. In contrast an Ethiopian study reported $14.3 \%$ of S.aureus isolates resistant to vancomycin[19,20].

\section{Conclusion: -}

This study revealed that most of ready- to - eat foods sold in the streets of Rajahmundry city failed to fulfill quality and safety standards required to prevent bacterial contamination of foods. Frequently isolated bacteria such as $E$. coli and $S$. aureus act as potential enteric pathogens and cause gastro-enteritis. Various steps involved right from preparation of such foods till they reach the customers plate must be scrutinized by periodical microbiological assessment. The local government should initiate and implement various control measures to improve the safety levels of food like educating the public regarding health hazards related to street food; training the food handlers and vendors to follow good hygienic and serving practices; ensuring proper sanitation of surroundings where foods are sold in public places. Regular surveillance of these foods for their microbiological quality is the need of the hour to prevent dissemination of multi drug resistant food borne pathogens in the community.

\section{ACKNOWLEDGMENTS}

Declaration of Conflicting Interests: The authors declare that they have no conflict of interest.

Financial Disclosure: No financial support was received.

\section{REFERENCES}

1. Mensah P, Yeboah-Manu D, Owusu-Darko K, Ablordey A. Street foods in Accra, Ghana: how safe are they? Bull. WHO 2002; 80: 546-554.

2. Muinde AM, Kuria E. Hygienic and sanitary practices of vendors of street foods in Nairobi. Kenya. AJFAND 2005; 5: 1-13.

3. Barro N, Bello AR, Aly S, Ouattara CAT, Ilboudo AJ, Traoré AS. Hygienic status and assessment of dishwashing waters, utensils, hands, and pieces of money from street food processing sites in Ouagadougou (Burkina Faso). African Journal of Biotechnology 2006; 5 (11): 1107-1112.

4. Barro N, Bello AR, Itsiembou $\mathrm{Y}$, et al. Street vended foods Improvement: Contamination Mechanism and Application of food safety objective strategy: Critical Review. Pakistan Journal of Nutrition 2007; 6(1):1-10.

5. Hanoshiro A, Morita M, Matte GR, Matte MH, Torres EAFS. Microbiological quality of selected foods from a restricted area of Sao Paulo City, Brazil. Food control 2004; 16: 439-444.

6. Ghosh M, Wahi S, Ganguli KM. Prevalence of enterotoxigenic Staphylococcus aureus and Shigella spp. in some raw street vended Indian foods. Int J Environ Health Res 2007; 17(2): 151 156.

7. Bhaskar J, Usman M, Smitha S, Bhat GK. Bacteriological profile of street foods in Mangalore. Indian J Med Microbiol 2004; 22: 197. 
8. Chumber SK, Kaushik K, Savy S. Bacteriological analysis of street foods in Pune, Indian J Public Health 2007; 51(2): 114-116.

9. Kabwama SN, Bulage L, Nsubuga F, et al. A large and persistent outbreak of typhoid fever caused by consuming contaminated water and street-vended beverages: Kampala, Uganda, January - June 2015. BMC Public Health 2017; 17(1):23.

10. Donado-Godoy $P$, Byrne BA, León $M$, et al. Prevalence, resistance patterns, and risk factors for antimicrobial resistance in bacteria from retail chicken meat in Colombia. J Food Prot 2015; 78(4):751-759.

11. Kalter HD1, Gilman RH, Moulton LH, Cullotta AR, Cabrera L, Velapatiño B. Risk factors for antibiotic-resistant Escherichia coli carriage in young children in Peru: community-based crosssectional prevalence study. Am J Trop Med Hyg 2010; 82(5):879-888.

12. Tambekar DH, Jaiswal VJ, Dhanorkar DV, Gulhane PB, Dudhane MN. Identification of microbiological hazards and safety of ready-to-eat food vended streets of Amravati City, India. Journal of Applied BioSciences 2008; 7: 195-201.

13. Hi-Media Manual for Microbiology and Cell Culture Laboratory Practices, $2016 . \quad H i-m e d i a$ Laboratories, Pvt. Ltd, Mumbai, India, pp. 69.

14. Collee JG, Duguid IP, Fraser AG, Marmion BP, 1996. Enterobacteriaceae- Escherichia, Klebsiella, Proteus and other genera. Pp 137-149, In: Collee JG, Duguid JP, Froser AG, Marmion BP. (ed 5.), Practical Medical Microbiology.

15. George EA, Sankar S, Jesudasan MV, Sudandiradoss C, Nandagopal B. Incidence of extended spectrum beta lactamase producing Escherichia coli among Patients, Healthy individuals and in environment. Indian $\mathrm{J}$ Med Microbiol 2014; 32:172-4.

16. Gupta M, Singh N P, Kumar A, Kaur I R. Cefoxitin disk diffusion test - Better predictor of methicillin resistance in Staphylococcus aureus. Indian J Med Microbiol 2009; 27:379-380.

17. Estrada-Garcia T, Lopez-Sancedo C, ZamarripaAyala B, Thompson MR, Gutierrez L. Prevalence of Escherichia coli and Salmonella spp. in street vended food of open markets and general hygienic and trading practices in Mexico City. Epidemiol Infect 2004; 132:1181-4.

18. Feglo and Sakyi.. Bacterial contamination of street vending food in Kumasi, Ghana. J Med Biomedical Scienc 2012;1(1): 1-8.

19. Oladipo IC, Adejumobi Od. Incidence of Antibiotic Resistance in Some Bacterial Pathogens from Street Vended Food in Ogbomoso, Nigeria. Pak Jf Nutrit 2010;9(11):1061-1068.
20. Temesgen Eromo, Haimanot Tassew and Gebre Kibru. Bacteriological Quality of Street Foods and Antimicrobial Resistance of Isolates in Hawassa, Ethiopia. Ethiop J Health Sci 2016; 26(9):533-40. 